\title{
Different Characteristics of Serum Alfa Fetoprotein and Serum Des-gamma-carboxy Prothrombin in Resected Hepatocellular Carcinoma
}

\author{
MASAMICHI HAYASHI ${ }^{1}$, SUGURU YAMADA ${ }^{1}$, NAO TAKANO ${ }^{1}$, YUKIYASU OKAMURA ${ }^{2}$, \\ HIDEKI TAKAMI ${ }^{1}$, YOSHIKUNI INOKAWA ${ }^{1}$, FUMINORI SONOHARA ${ }^{1}$, NOBUTAKE TANAKA ${ }^{1}$, \\ DAI SHIMIZU ${ }^{1}$, NORIFUMI HATTORI ${ }^{1}$, MITSURO KANDA ${ }^{1}$, CHIE TANAKA $^{1}$, \\ GORO NAKAYAMA ${ }^{1}$, MASAHIKO KOIKE ${ }^{1}$ and YASUHIRO KODERA ${ }^{1}$ \\ ${ }^{1}$ Department of Gastroenterological Surgery, Nagoya University Graduate School of Medicine, Nagoya, Japan; \\ ${ }^{2}$ Division of Hepato-Biliary-Pancreatic Surgery, Shizuoka Cancer Center, Shizuoka, Japan
}

\begin{abstract}
Background/Aim: Hepatocellular carcinoma (HCC) mainly develops in the damaged liver from hepatitis $C$ virus $(H C V)$ or hepatitis $B$ virus (HBV) infection in Japan. On the other hand, the occurrence of HCCs derived from the liver without viral infection has recently been increasing. Our aim was to identify characteristics specific to $\mathrm{HCCs}$ with virus-infected liver $(\mathrm{HCC}-\mathrm{BC})$ or those with non-B-and non-C-infected liver (HCC-NBNC), Patients and Methods: We collected preoperative serum $\alpha$-fetoprotein (AFP) and Des-Gamma-Carboxy Prothrombin (DCP), also known as PIVKA-II values from surgically resected HCC cases during 1994-2017 in our department. Results: Preoperative serum AFP values of HCC-BC cases $(n=284)$ were higher compared to HCC-NBNC cases (n=88) ( $p=0.016)$, whereas serum DCP values of HCC-NBNC cases were higher compared to HCC-BC cases $(p<0.001)$. Multivariable analyses indicated that abnormal serum AFP [hazard ratio $(H R)=1.46,95 \%$ conficdence interval $(C I)=1.03-2.07, p=0.035)$ was one of the significant recurrence-free survival predictors of $H C C-B C$ cases, while abnormal serum DCP $(H R=4.99,95 \% C I=1.91-13.01$, $p=0.001$ ) was one of the significant recurrence-free survival predictors of $\mathrm{HCC}-\mathrm{NBNC}$ cases. Conclusion: HCC-NBNC cases have a different tumor marker profile from $H C C-B C$
\end{abstract}

This article is freely accessible online.

Correspondence to: Suguru Yamada, Department of Gastroenterological Surgery, Nagoya University Graduate School of Medicine, 65 Tsurumai-cho, Showa-ku, Nagoya, 466-8550, Japan. Tel: +41 0527442249, Fax: +41 0527442252, e-mail: suguru@med.nagoya-u.ac.jp

Key Words: AFP, DCP, hepatocellular carcinoma, survival predictor. cases. Elevated DCP could be both a diagnostic and prognostic marker of HCC-NBNC patients.

Hepatocellular carcinoma (HCC) is the $6^{\text {th }}$ most frequently occuring cancer globally and still has a high likelihood of recurrence and a poor prognosis (1). HCCs are mainly derived from the damaged liver caused by various etiological factors, including hepatitis $\mathrm{C}$ virus $(\mathrm{HCV})$ or hepatitis $\mathrm{B}$ virus (HBV) infection, as well as chronic alcohol abuse (2, 3). Among them, $\mathrm{HCV}(65 \%)$ and $\mathrm{HBV}(15 \%)$ are the two major pathogenic factors in Japan (4). Recently, the occurrence of HCCs derived from non-B non-C livers (HCC$\mathrm{NBNC}$ ) have been relatively increasing because $\mathrm{HBV}$ or $\mathrm{HCV}$ treatments have dramatically improved. HCC-NBNC lesions typically arise from non-alcoholic steatohepatitis (NASH) or alcoholic liver disease.

To characterize the background liver status, whole-genome analyses have been widely performed $(5,6)$. Some mutational signatures and altered pathways have been associated with certain histological characteristics of background livers or tumor stages $(7,8)$. For instance, the mutation of catenin beta $1(C T N N B 1)$, one of the critical cluster of Wnt-signaling, has been related to alcoholdamaged liver. Telomerase reverse transcriptase (TERT), cyclin dependent kinase inhibitor 2A (CDKN2A), SWI/SNF related, matrix associated, actin dependent regulator of chromatin, subfamily a, member 2 (SMARCA2) and hepatocyte growth factor $(H G F)$ alterations are also enriched in alcohol-related HCC patients. Tumor protein p53 (TP53) mutations are frequently associated with HBV infection. The integration of $\mathrm{HBV}$ into the host genome $(9,10)$ induces upregulation of cancer-related genes, such as TERT, lysine methyltransferase 2B (MLL4), and cyclin E1 (CCNE1) genes. This leads to alterations in the genes functioning downstream of all these genes or cause whole genome 
chromosomal instability $(10,11)$. Concerning the HCCNBNC and background liver, Kutlu et al. have reported severral molecular characteristics (12), including a patatinlike phospholipase domain containing 3 (PNPLA3) gene mutation, epigenetic changes of phosphodiedterase $1 \mathrm{~B}$ (PDE1B) and chromodomain helicase DNA-binding protein 1 (CHDl) , micro RNA deregulation including miR-122, metabolic pathway activating insulin receptor signaling and mitochondrial dysfunction caused by reactive oxygen species and endoplasmic reticulum stress.

We hypothesized that some molecular characteristics distinguishing HCC-NBNC from HCC with virus-infected liver (HCC-BC) may affect the positivity of well-known tumor markers of HCC, such as alpha-fetoprotein (AFP) and desgamma-carboxy prothrombin (DCP) (13). In this study, we used the $\mathrm{HCC}$ resection cohort in our institution and retrospectively compared HCC-NBNC cases with HCC-BC cases from the viewpoint of these well-known HCC serum tumor markers.

\section{Patients and Methods}

Patient cohort. Among surgically resected HCC cases from 1994 to 2017 in the Department of Gastroenterological Surgery, at Nagoya University (Aichi, Japan), 372 cases with available preoperative AFP and DCP markers were included (Institute Review Board approvealnumber: 2013-0295). Of these, 284 patients were categorized as HCC-BC and 88 patients as HCC-NBNC. The average follow-up period was 51.4 months. Clinical factors including age, gender, liver damage scores, tumor size and numbers, and pathological factors of tumor differentiation, growth pattern, capsule formation, serosal and vascular invasion were categorically compared between the two groups.

Serum marker collection. Each serum marker was checked by peripheral blood examination preoperatively. The standard institutional cut-off values were $10 \mathrm{ng} / \mathrm{ml}$ for AFP and $40 \mathrm{mAU} / \mathrm{ml}$ for DCP.

Statistical analysis. Patient clinicopathological characteristics were compared using Fisher's exact test for categorical variables and Mann-Whitney $U$-test for continuous variables. Overall survival (OS) was defined as the time from surgery to the date of HCC disease-related death. Recurrence-free survival (RFS) was defined as the time from surgery to the date of recurrence diagnosis. Those who remained alive were censored at the last date they were known to be alive. A log-rank test was applied to compare the survival outcomes of the two groups. The Cox proportional hazards model was used for univariate and multivariable analysis for survival outcomes. All tests were considered statistically significant and clinically promising at $p<0.05$. Statistical analyses were carried out using the JMP 15 software (SAS Institute Japan, Tokyo, Japan).

\section{Results}

Patients characteristics. Clinicohistological characteristics of both HCC-BC cases $(n=284)$ and HCC-NBNC cases $(n=88)$ are shown in Table I. Due to the viral hepatic damage, liver damage score $\mathrm{B} / \mathrm{C}$ cases were more frequently
Table I. Patient characteristics

\begin{tabular}{|c|c|c|c|}
\hline Factors & $\begin{array}{c}\mathrm{HCC}-\mathrm{BC} \\
(\mathrm{n}=284)\end{array}$ & $\begin{array}{c}\text { HCC-NBNC } \\
\quad(\mathrm{n}=88)\end{array}$ & $p$-Value \\
\hline Age & & & 0.582 \\
\hline$\geq 60$ & 207 & 67 & \\
\hline$<60$ & 77 & 21 & \\
\hline Gender & & & 0.348 \\
\hline Female & 56 & 13 & \\
\hline Male & 228 & 75 & \\
\hline Liver Damage & & & 0.071 \\
\hline A & 218 & 76 & \\
\hline $\mathrm{B} / \mathrm{C}$ & 66 & 12 & \\
\hline Tumor number & & & 0.121 \\
\hline Single & 207 & 72 & \\
\hline Multiple & 77 & 16 & \\
\hline Tumor size & & & $<0.001$ \\
\hline$\geq 2.0 \mathrm{~cm}$ & 151 & 70 & \\
\hline$<2.0 \mathrm{~cm}$ & 133 & 18 & \\
\hline Differentiation & & & 0.753 \\
\hline Well & 50 & 17 & \\
\hline Moderate/Poor & 230 & 71 & \\
\hline Unknown & 4 & 0 & \\
\hline Growth pattern & & & 0.197 \\
\hline Expansive & 236 & 67 & \\
\hline Invasive & 45 & 19 & \\
\hline Unknown & 3 & 2 & \\
\hline Capsule formation & & & 0.896 \\
\hline Positive & 192 & 58 & \\
\hline Negative & 92 & 29 & \\
\hline Unknown & 0 & 1 & \\
\hline Infiltration to capsule & & & 0.806 \\
\hline Positive & 155 & 46 & \\
\hline Negative & 128 & 41 & \\
\hline Unknown & 1 & 1 & \\
\hline Septal formation & & & 0.294 \\
\hline Positive & 182 & 61 & \\
\hline Negative & 97 & 24 & \\
\hline Unknown & 5 & 3 & \\
\hline Serosal invasion & & & 0.045 \\
\hline Positive & 48 & 25 & \\
\hline Negative & 202 & 57 & \\
\hline Unknown & 34 & 6 & \\
\hline Portal vein invasion & & & 1.000 \\
\hline Positive & 56 & 17 & \\
\hline Negative & 226 & 69 & \\
\hline Unknown & 2 & 2 & \\
\hline Hepatic vein invasion & & & 0.027 \\
\hline Positive & 30 & 18 & \\
\hline Negative & 248 & 68 & \\
\hline Unknown & 6 & 2 & \\
\hline LCSGJ stage & & & 1.000 \\
\hline I-II & 178 & 55 & \\
\hline III-IV & 105 & 33 & \\
\hline Unknown & 1 & 0 & \\
\hline Liver cirrhosis & & & $<0.001$ \\
\hline Positive & 126 & 19 & \\
\hline Negative & 158 & 69 & \\
\hline AFP & & & 0.061 \\
\hline$\leq 10 \mathrm{ng} / \mathrm{ml}$ & 107 & 43 & \\
\hline$>10 \mathrm{ng} / \mathrm{ml}$ & 171 & 43 & \\
\hline Unknown & 6 & 2 & \\
\hline DCP & & & $<0.001$ \\
\hline$\leq 40 \mathrm{mAU} / \mathrm{ml}$ & 139 & 23 & \\
\hline$>40 \mathrm{mAU} / \mathrm{ml}$ & 115 & 62 & \\
\hline Unknown & 30 & 3 & \\
\hline
\end{tabular}

HCC-BC: Hepatocellular carcinoma with virus-infected liver; HCCNBNC: hepatocellular carcinoma with no virus-infected liver; LCSGJ: Liver Cancer Study Group of Japan; AFP: $\alpha$-fetoprotein; DCP: desgamma-carboxy prothrombin. Significant $p$-Values are shown in bold. 

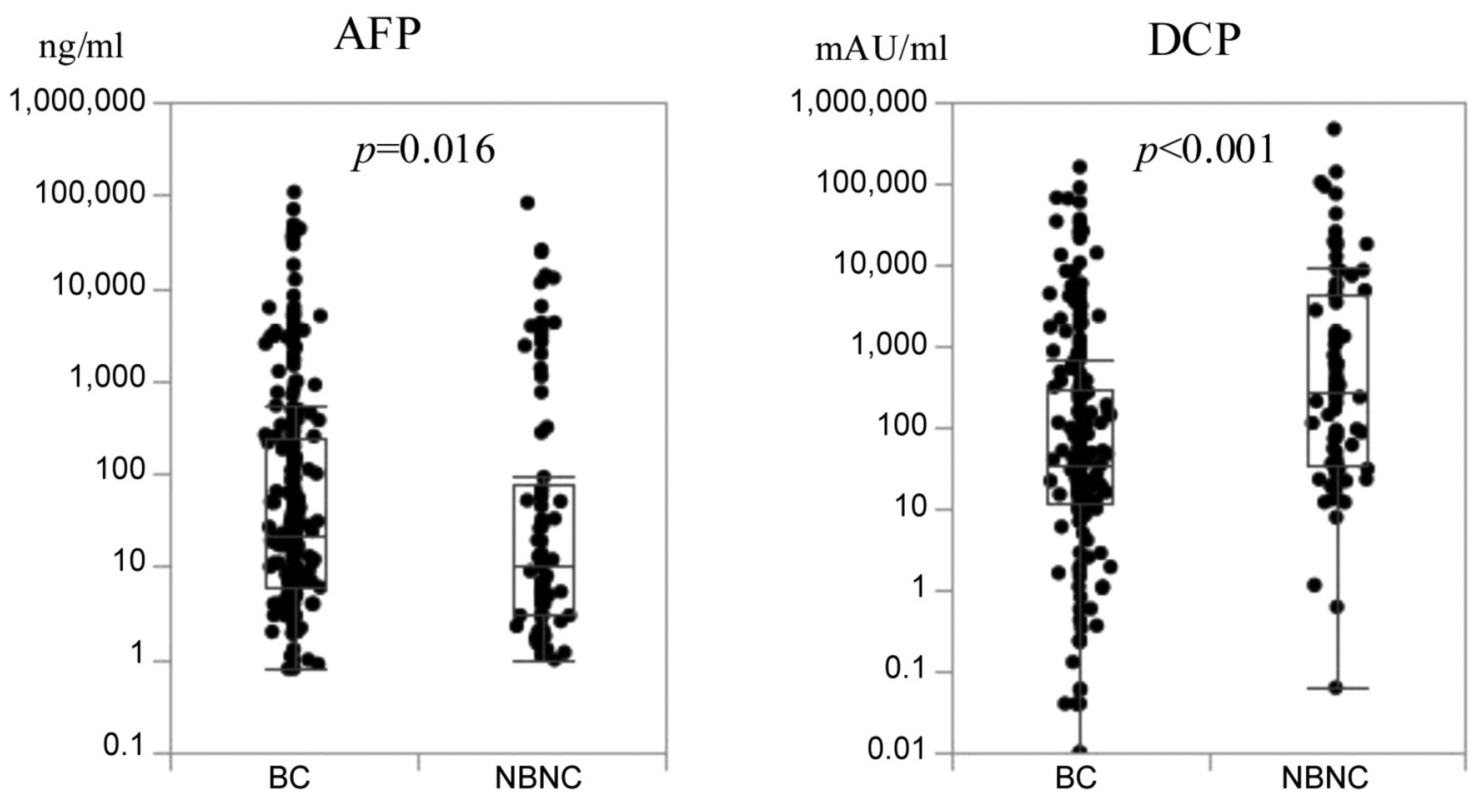

Figure 1. Preoperative AFP and DCP values of HCC-BC and HCC-NBNC cases. HCC-BC cases ( $n=284)$ had significantly higher AFP values compared to the NBNC cohort, while HCC-NBNC cases $(n=88)$ had significantly higher DCP values compared to the BC cohort. AFP: Alphafetoprotein; DCP: des-gamma-carboxy prothrombin; HCC-BC: hepatocellular carcinoma with virus-infected liver; HCC-NBNC: hepatocellular carcinoma with no virus-infected liver.

found in $\mathrm{HCC}-\mathrm{BC}$ rather than in $\mathrm{HCC}-\mathrm{NBNC}$ cases $(p=0.071)$. Histologically advanced cases with large diameter $(p<0.001)$, serosal invasion $(p=0.045)$ and hepatic vein invasion $(p=0.027)$ were frequently found in HCC-NBNC cases, while the cancer stage distributions of Liver Cancer Study Group of Japan (LCSGJ) between the two groups were comparable $(p=1.000)$. The distribution of actual serum values for AFP and DCP were compared between HCC-BC and HCC-NBNC cases, as depicted in Figure 1. AFP values were inclined to exceed the cut-off value in $\mathrm{HCC}-\mathrm{BC}$ cases $(p=0.061)$, whereas DCP values were significantly higher in HCC-NBNC cases compared to HCC-BC cases $(p<0.001)$.

Serum tumor marker and survival outcomes. We compared high and low tumor marker cases based on the cut-off values in each HCC-BC and HCC-NBNC cohort to ascertain the markes' impact on postoperative RFS and OS. With regards to RFS (Figure 2), cases with aberrantly high values of tumor markers showed significantly poor survival outcomes in both cohorts. Concerning OS (Figure 3), high AFP was associated with a significantly poor prognosis in the HCCBC cohort. In contrast, patients with high DCP had significantly lower OS in both cohorts, with a vast difference in OS between high and low values in the HCC-HBNC cohort. Then, we compared AFP high with AFP low (Table II) as well as DCP high with DCP low (Table III) in the HCC-BC amd HCC-NBNC cohorts to examine the charactiristics associates with these values in detail. High AFP cases were related to aged people, with i) moderate or poor differentiation, ii) portal vein invasion, iii) advanced tumor stage and iv) positive liver cirrhosis, while high AFP cases were also specific to the HCC-NBNC cohort with both i) portal vein invasion and ii) advanced tumor stage. On the contrary, high DCP cases were significantly correlated with HCC-BC cases with i) a large tumor size, ii) moderate or poor differentiation, iii) infiltration to a capsule, iv) serosal invasion, v) vascular invasion, vi) advanced tumor stage and vii) liver cirrhosis. Also, they were associated with HCCNBNC with i) large tumor size and ii) moderate or poor differentiation.

Univariate and multivariable analyses of survival outcomes. Univariate and multivariable analyses of survival outcomes were performed. All significant factors in the univariate analysis were put into the multivariable analysis. The backward stepwise method was performed until the $p$-Values of all remaining factors became significant. Tables IV and V summarize the results of RFS in the HCC-BC and HCCNBNC cohorts. In HCC-BC cases, i) tumor size, ii) AFP elevation, iii) serosal invasion, iv) portal vein invasion and v) hepatic vein invasion were detected as significant prognostic factors of RFS in multivariable analysis. On the other hand, i) DCP elevation and ii) portal vein invasion were significant factors in HCC-NBNC cases. 


\section{High / Low AFP in HCC-BC cases}

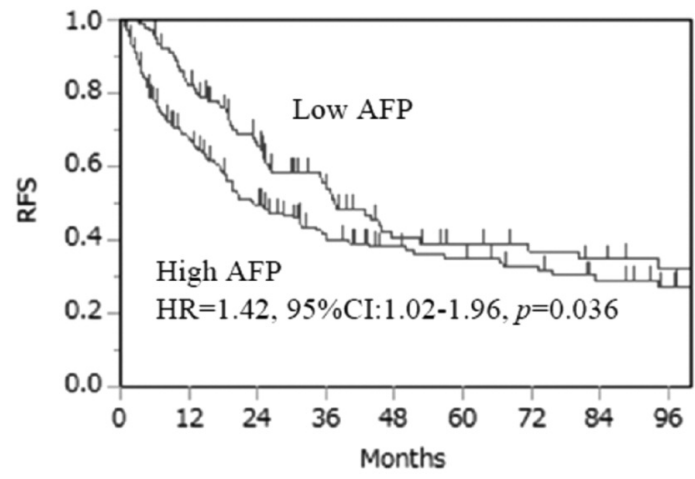

Number at risk

$\begin{array}{llllll}\text { Low AFP } & 107 & 58 & 26 & 19 & 14\end{array}$

High AFP 171

\section{High / Low DCP in HCC-BC cases}

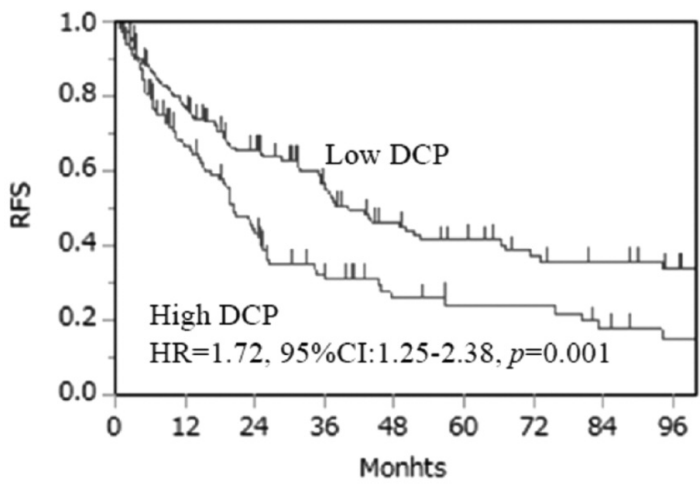

Number at risk

Low DCP 139

High DCP 115

$\begin{array}{rrrr}76 & 40 & 26 & 19 \\ 40 & 16 & 13 & 6\end{array}$

\section{High / Low AFP in HCC-NBNC cases}

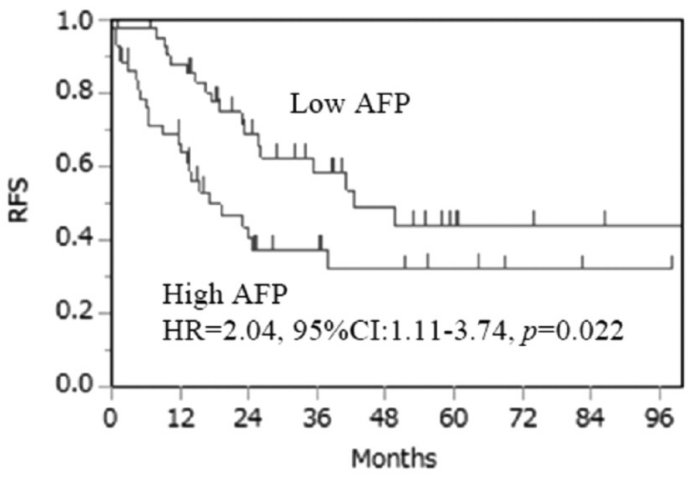

Number at risk

Low AFP 43

High AFP 43

\section{High / Low DCP in HCC-NBNC cases}

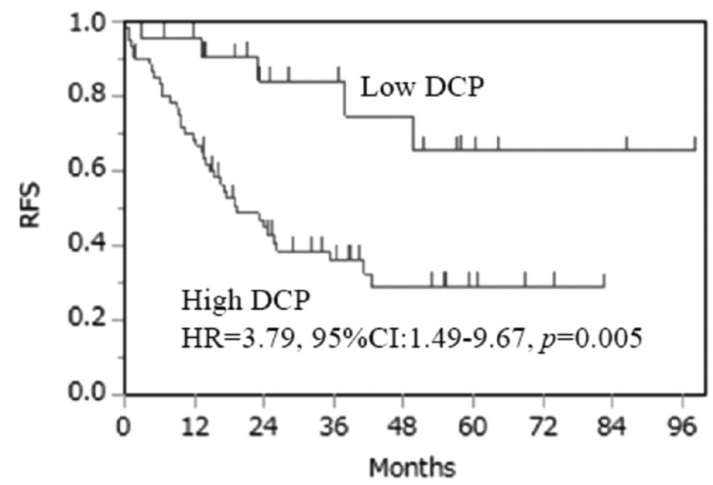

Number at risk

Low DCP 23

High DCP 62

$\begin{array}{lccc}23 & 11 & 4 & 2 \\ 15 & 7 & 3 & 2\end{array}$

Figure 2. Recurrence-free survival curves (RFS). RFS was compared between high AFP cases (AFP>10ng/ml) and low AFP cases, as well as high $D C P$ cases $(D C P>40 \mathrm{mAU} / \mathrm{ml})$ and low DCP cases in both HCC-BC and HCC-NBNC cohorts. Both serum markers indicated significantly poor survival outcomes in both cohorts. AFP: Alpha-fetoprotein; DCP: des-gamma-carboxy prothrombin; HCC-BC: hepatocellular carcinoma with virusinfected liver; HCC-NBNC: hepatocellular carcinoma with no virus-infected liver.

Tables VI and VII demonstrate the results of OS in each cohort. In the multivariable analysis of HCC-BC cases i) tumor number, ii) serosal invasion, iii) portal vein invasion and iv) hepatic vein invasion were significant predictors. In contrast, i) DCP elevation was an extremely significant predictor of HCC-NBNC cases in addition to ii) serosal invasion and iii) portal vein invasion. None of the low DCP cases died from the disease in our cohort.

Clinical characteristics of AFP and DCP elevation. AFP values of $\mathrm{HCC}-\mathrm{BC}$ cases increased depending on tumor $\mathrm{T}$ stage, while DCP values of HCC-NBNC cases increased depending on the T stage (Figure 4). Besides, the association of both markers with background liver are shown in Figure 5. AFP does not decrease in the cirrhotic liver, while DCP decreases in them.

\section{Discussion}

Clinically, the measurement of both AFP and DCP has been strongly recommended in the Clinical Practice Guidelines for Hepatocellular Carcinoma (14); however, the mechanism of each tumor marker elevation is unknown and may differ bweteen tumor types. HCCs derived from NBNC are 


\section{High / Low AFP in HCC-BC cases}

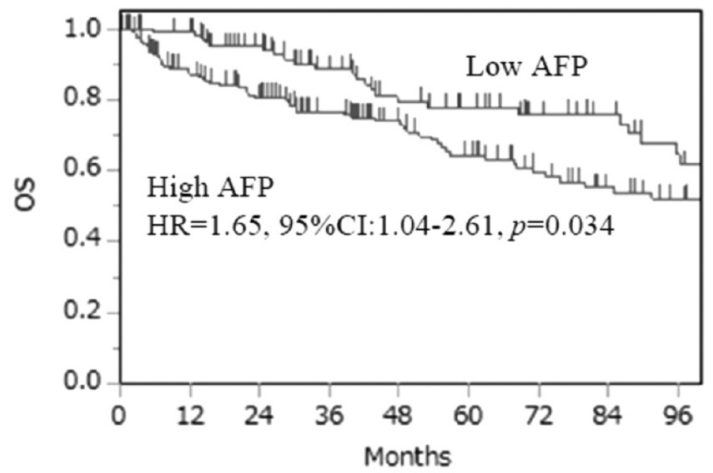

Number at risk

Low AFP 107

High AFP 171
83

50

73
35

46

\section{High / Low AFP in HCC-NBNC cases}

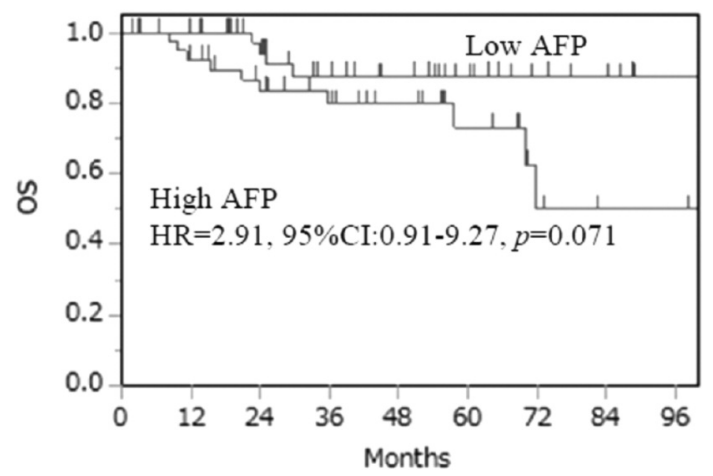

\section{High / Low DCP in HCC-BC cases}

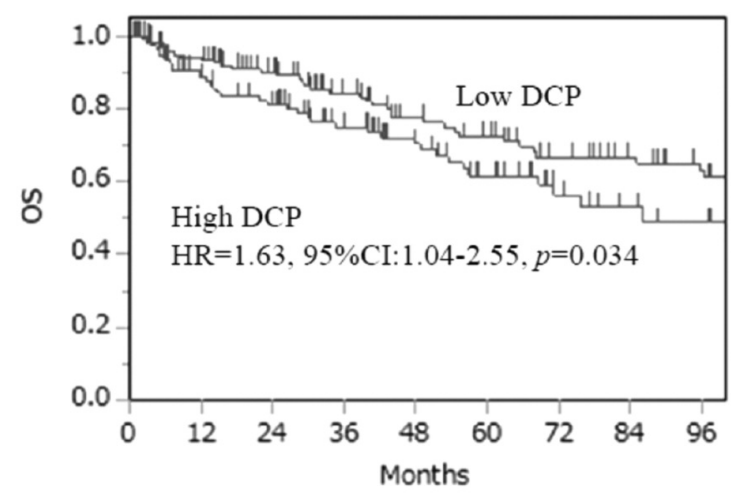

Number at risk

Low DCP 139

High DCP 115

101
75

64

43

\begin{abstract}
46
\end{abstract}
20

32

12
Number at risk

Low AFP 43

High AFP 43
20

29

\section{High / Low DCP in HCC-NBNC cases}

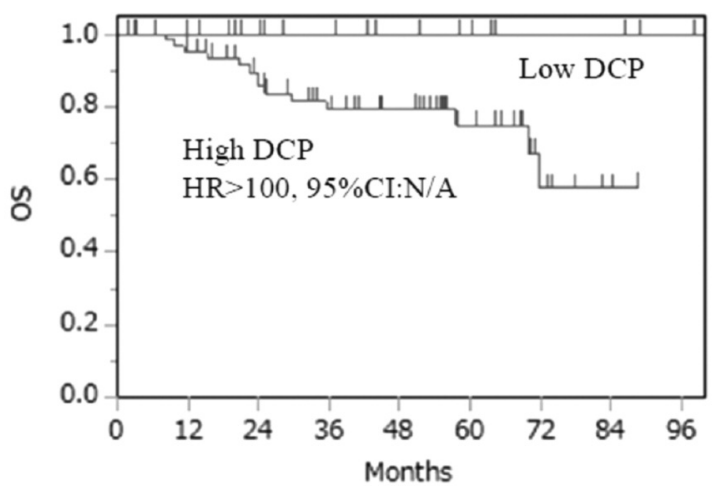

Number at risk

Low DCP 23

High DCP 62

16
46

9

29

5

3

Figure 3. Overall survival (OS). OS curves were compared between high AFP cases (AFP>10ng/ml) and low AFP cases, and high DCP cases $(D C P>40 \mathrm{mAU} / \mathrm{ml})$ and low DCP cases in the HCC-BC cohort and HCC-NBNC cohort, respectively. High AFP indicated significantly poor survival outcomes in the HCC-BC cohort, while high DCP displayed significantly poor survival outcomes in both cohorts. AFP: Alpha-fetoprotein; DCP: des-gamma-carboxy prothrombin; HCC-BC: hepatocellular carcinoma with virus-infected liver; HCC-NBNC: hepatocellular carcinoma with no virus-infected liver.

reported to have relatively low serum AFP levels compared to hepatitis B-derived HCCs (15). Also, hepatitis C-infected livers usually have high serum AFP levels (16). These findings suggest that AFP elevation is commonly influenced by a viral infection of the background liver. AFP is a glycoprotein derived from the embryonic endoderm. It is closely related to the growth of malignant tumors (17). During embryonic development, AFP is initially produced in the fetal liver and yolk sac. The serum AFP concentration increases during the period between 12-16 weeks of gestation and then it gradually reduces to normal range till adulthood (18). AFP increases again during early stages of hepatocytes' malignant transformation, and it is activated in the malignant cells. Zheng Y et al., have summarized the AFP production mechanism in $\mathrm{HBV}$-derived hepatitis-based HCCs (17), where the HBV $X$ protein promotes the acceleration of AFP's accretion, which induces growth signal activation, metastases and bears an immunosuppressive role.

Instead, DCP is abnormal prothrombin and produced due to the defect of the post-translational carboxylation of prothrombin's precursor (19); however, the detailed mechanism of its production is unclear. Taniguchi $\mathrm{T}$ et al. have used mass spectrometry analysis of hepatoma cell lines to reveal that PARP-1 activates prothrombin gene 
Table II. Clinicohistological features of AFP high cases.

\begin{tabular}{|c|c|c|c|c|c|c|}
\hline \multirow[t]{2}{*}{ Factors } & \multicolumn{2}{|c|}{ HCC-BC } & \multirow[t]{2}{*}{$p$-Value } & \multicolumn{2}{|c|}{ HCC-NBNC } & \multirow[t]{2}{*}{$p$-Value } \\
\hline & AFP high & AFP low & & AFP high & AFP low & \\
\hline Age & & & 0.018 & & & 1.000 \\
\hline$\geq 60$ & 116 & 87 & & 32 & 33 & \\
\hline$<60$ & 55 & 20 & & 11 & 10 & \\
\hline Gender & & & 0.759 & & & 0.549 \\
\hline Female & 35 & 20 & & 35 & 38 & \\
\hline Male & 136 & 87 & & 8 & 5 & \\
\hline Liver damage & & & 0.773 & & & 0.351 \\
\hline A & 132 & 81 & & 39 & 35 & \\
\hline $\mathrm{B} / \mathrm{C}$ & 39 & 26 & & 4 & 8 & \\
\hline Tumor number & & & 0.332 & & & 1.000 \\
\hline Single & 121 & 82 & & 35 & 35 & \\
\hline Multiple & 50 & 25 & & 8 & 8 & \\
\hline Tumor size & & & 0.462 & & & 0.792 \\
\hline$\geq 2.0 \mathrm{~cm}$ & 88 & 60 & & 33 & 35 & \\
\hline$<2.0 \mathrm{~cm}$ & 83 & 47 & & 10 & 8 & \\
\hline Differentiation & & & 0.006 & & & 0.103 \\
\hline Well & 21 & 28 & & 5 & 12 & \\
\hline Moderate/Poor & 147 & 78 & & 38 & 31 & \\
\hline Growth pattern & & & 0.739 & & & 0.186 \\
\hline Expansive & 139 & 91 & & 31 & 35 & \\
\hline Invasive & 29 & 16 & & 12 & 6 & \\
\hline Capsule formation & & & 0.114 & & & 0.818 \\
\hline Positive & 122 & 66 & & 29 & 28 & \\
\hline Negative & 49 & 41 & & 13 & 15 & \\
\hline Infiltration to capsule & & & 0.047 & & & 0.517 \\
\hline Positive & 101 & 50 & & 24 & 21 & \\
\hline Negative & 69 & 57 & & 18 & 22 & \\
\hline Septal formation & & & 0.796 & & & 1.000 \\
\hline Positive & 110 & 66 & & 30 & 29 & \\
\hline Negative & 59 & 38 & & 12 & 12 & \\
\hline Serosal invasion & & & 0.415 & & & 0.144 \\
\hline Positive & 31 & 17 & & 15 & 9 & \\
\hline Negative & 113 & 84 & & 24 & 32 & \\
\hline Portal vein invasion & & & 0.019 & & & 0.003 \\
\hline Positive & 41 & 13 & & 14 & 3 & \\
\hline Negative & 129 & 93 & & 27 & 40 & \\
\hline Hepatic vein invasion & & & 0.555 & & & 0.113 \\
\hline Positive & 20 & 10 & & 12 & 6 & \\
\hline Negative & 145 & 97 & & 29 & 37 & \\
\hline LCSGJ stage & & & 0.040 & & & 0.026 \\
\hline I-II & 99 & 76 & & 21 & 32 & \\
\hline III-IV & 71 & 31 & & 22 & 11 & \\
\hline Liver cirrhosis & & & 0.047 & & & 0.604 \\
\hline Positive & 84 & 39 & & 11 & 8 & \\
\hline Negative & 87 & 68 & & 32 & 35 & \\
\hline $\mathrm{DCP}$ & & & 0.796 & & & 0.465 \\
\hline$\leq 40 \mathrm{mAU} / \mathrm{ml}$ & 80 & 56 & & 13 & 9 & \\
\hline$>40 \mathrm{mAU} / \mathrm{ml}$ & 68 & 44 & & 30 & 31 & \\
\hline
\end{tabular}

HCC-BC: Hepatocellular carcinoma with virus-infected liver; HCC-NBNC: hepatocellular carcinoma with no virus-infected liver; LCSGJ: Liver Cancer Study Group of Japan; AFP: $\alpha$-fetoprotein; DCP: des-gamma-carboxy prothrombin. Significant $p$-Values are shown in bold.

transcription and that this excessive transcription induces DCP production (20). PARP-1 inhibition is also reported as a candidate therapeutic strategy for hepatic triglyceride accumulation, metabolic dysregulation, inflammation and fibrosis in mouse NASH models (21). DCP elevation reflects vascular invasion and tumor recurrences following 
Table III. Clinicohistological features of DCP high cases.

\begin{tabular}{|c|c|c|c|c|c|c|}
\hline \multirow[t]{2}{*}{ Factors } & \multicolumn{2}{|c|}{$\mathrm{HCC}-\mathrm{BC}$} & \multirow[t]{2}{*}{$p$-Value } & \multicolumn{2}{|c|}{ HCC-NBNC } & \multirow[t]{2}{*}{$p$-Value } \\
\hline & DCP high & DCP low & & DCP high & DCP low & \\
\hline Age & & & 0.267 & & & 1.000 \\
\hline$\geq 60$ & 86 & 94 & & 15 & 6 & \\
\hline$<60$ & 29 & 45 & & 47 & 17 & \\
\hline Gender & & & 0.204 & & & 0.742 \\
\hline Female & 18 & 31 & & 9 & 4 & \\
\hline Male & 97 & 108 & & 53 & 19 & \\
\hline Liver damage & & & 0.174 & & & 0.727 \\
\hline A & 94 & 103 & & 54 & 19 & \\
\hline $\mathrm{B} / \mathrm{C}$ & 21 & 36 & & 8 & 4 & \\
\hline Tumor number & & & 0.162 & & & 0.750 \\
\hline Single & 77 & 105 & & 50 & 20 & \\
\hline Multiple & 38 & 34 & & 12 & 3 & \\
\hline Tumor size & & & $<0.001$ & & & 0.002 \\
\hline$\geq 2.0 \mathrm{~cm}$ & 85 & 60 & & 55 & 13 & \\
\hline$<2.0 \mathrm{~cm}$ & 30 & 79 & & 7 & 10 & \\
\hline Differentiation & & & $<0.001$ & & & 0.013 \\
\hline Well & 9 & 35 & & 8 & 9 & \\
\hline Moderate/Poor & 104 & 103 & & 54 & 14 & \\
\hline Growth pattern & & & 0.736 & & & 0.771 \\
\hline Expansive & 97 & 112 & & 48 & 17 & \\
\hline Invasive & 18 & 24 & & 13 & 6 & \\
\hline Capsule formation & & & 0.285 & & & 0.439 \\
\hline Positive & 81 & 88 & & 43 & 14 & \\
\hline Negative & 34 & 51 & & 18 & 9 & \\
\hline Infiltration to capsule & & & 0.043 & & & 0.469 \\
\hline Positive & 69 & 66 & & 35 & 11 & \\
\hline Negative & 45 & 73 & & 26 & 12 & \\
\hline Septal formation & & & 0.227 & & & 0.268 \\
\hline Positive & 77 & 86 & & 46 & 14 & \\
\hline Negative & 33 & 53 & & 14 & 8 & \\
\hline Serosal invasion & & & 0.013 & & & 0.177 \\
\hline Positive & 30 & 16 & & 21 & 4 & \\
\hline Negative & 79 & 102 & & 37 & 18 & \\
\hline Portal vein invasion & & & 0.001 & & & 1.000 \\
\hline Positive & 33 & 17 & & 12 & 4 & \\
\hline Negative & 81 & 122 & & 48 & 19 & \\
\hline Hepatic vein invasion & & & $<0.001$ & & & 0.134 \\
\hline Positive & 22 & 7 & & 16 & 2 & \\
\hline Negative & 89 & 132 & & 44 & 21 & \\
\hline LCSGJ stage & & & $<0.001$ & & & 0.459 \\
\hline I-II & 55 & 101 & & 37 & 16 & \\
\hline III-IV & 60 & 38 & & 25 & 7 & \\
\hline Liver cirrhosis & & & 0.030 & & & 0.379 \\
\hline Positive & 40 & 68 & & 12 & 7 & \\
\hline Negative & 75 & 71 & & 50 & 16 & \\
\hline
\end{tabular}

HCC-BC: Hepatocellular carcinoma with virus-infected liver; HCC-NBNC: hepatocellular carcinoma with no virus-infected liver; LCSGJ: liver cancer study group of Japan; AFP: $\alpha$-fetoprotein; DCP: des-gamma-carboxy prothrombin. Significant $p$-Values are shown in bold.

hepatectomy (22). It has also been reported to increase during epithelial to mesenchymal transition in tumors (23). In other words, DCP goes up by tumor factors.

Interestingly, Suzuki $\mathrm{H}$ et al., have reported that mild hypoxia induces HCC to produce DCP, while long-lasting hypoxia impaires DCP production in HCC cells (23), which could partly explain why DCP is elevated in HCC-NBNCs rather than in HCC-BCs. In our study tumor sizes of HCCNBNCs were significantly larger than HCC-BCs because no intensive follow-up examination was usually performed for NBNC patients. The relatively large HCC-NBNCs sometimes induce intratumoral hypoxia, which is easy to 
Table IV. Univariate and multivariable analyses of RFS in HCC-BC cases.

\begin{tabular}{|c|c|c|c|c|c|c|c|}
\hline \multirow{2}{*}{\multicolumn{2}{|c|}{ Clinicopathological factors }} & \multicolumn{3}{|c|}{ Univariate analysis } & \multicolumn{3}{|c|}{ Multivariable analysis } \\
\hline & & \multirow{2}{*}{$\begin{array}{l}\text { HR } \\
1.00\end{array}$} & \multirow{2}{*}{$\begin{array}{c}95 \% \mathrm{CI} \\
0.71-1.41\end{array}$} & \multirow{2}{*}{$\begin{array}{c}p \text {-Value } \\
0.983\end{array}$} & \multirow[t]{2}{*}{ HR } & \multirow[t]{2}{*}{$95 \% \mathrm{CI}$} & \multirow[t]{2}{*}{$p$-Value } \\
\hline Age & $\geq 65$ years & & & & & & \\
\hline Gender & Male & 1.34 & $0.88-2.02$ & 0.169 & & & \\
\hline Tumor number & Multiple & 1.66 & $1.20-2.31$ & 0.003 & & & \\
\hline Tumor size & $\geq 2.0 \mathrm{~cm}$ & 1.89 & $1.37-2.61$ & $<0.001$ & 1.66 & $1.15-2.39$ & 0.007 \\
\hline AFP & $\geq 10 \mathrm{ng} / \mathrm{ml}$ & 1.42 & $1.02-1.96$ & 0.036 & 1.46 & $1.03-2.07$ & 0.035 \\
\hline DCP & $\geq 40 \mathrm{ng} / \mathrm{ml}$ & 1.72 & $1.25-2.38$ & 0.001 & & & \\
\hline Differentiation & Poor, Moderate & 1.32 & $0.87-2.02$ & 0.193 & & & \\
\hline Growth form & Infiltrative & 1.70 & $1.15-2.52$ & 0.008 & & & \\
\hline Serosal invasion & Positive & 2.46 & $1.67-3.62$ & $<0.001$ & 1.94 & $1.30-2.89$ & 0.001 \\
\hline Portal vein invasion & Positive & 2.34 & $1.63-3.34$ & $<0.001$ & 1.88 & $1.26-2.81$ & 0.002 \\
\hline Hepatic vein invasion & Positive & 2.99 & $1.87-4.78$ & $<0.001$ & 2.67 & $1.65-4.32$ & $<0.001$ \\
\hline Liver cirrhosis & Present & 1.09 & $0.80-1.48$ & 0.598 & & & \\
\hline
\end{tabular}

RFS: Recurrence-free survival time; HCC-BC: hepatocellular carcinoma with virus-infected liver; AFP: $\alpha$-fetoprotein; DCP: des-gamma-carboxy prothrombin; HR: hazard ratio; CI: confidence interval.

Table V. Univariate and multivariable analyses of RFS in HCC-NBNC cases.

\begin{tabular}{|c|c|c|c|c|c|c|c|}
\hline \multirow{2}{*}{\multicolumn{2}{|c|}{ Clinicopathological factors }} & \multicolumn{3}{|c|}{ Univariate analysis } & \multicolumn{3}{|c|}{ Multivariable analysis } \\
\hline & & \multirow{2}{*}{$\begin{array}{l}\mathrm{HR} \\
1.09\end{array}$} & \multirow{2}{*}{$\begin{array}{c}95 \% \mathrm{CI} \\
0.55-2.16\end{array}$} & \multirow{2}{*}{$\frac{p \text {-Value }}{0.805}$} & \multirow[t]{2}{*}{ HR } & \multirow[t]{2}{*}{$95 \% \mathrm{CI}$} & \multirow[t]{2}{*}{$p$-Value } \\
\hline Age & $\geq 65$ years & & & & & & \\
\hline Gender & Male & 1.54 & $0.61-3.91$ & 0.366 & & & \\
\hline Tumor number & Multiple & 1.90 & $0.90-4.00$ & 0.090 & & & \\
\hline Tumor size & $\geq 2.0 \mathrm{~cm}$ & 2.23 & $0.94-5.30$ & 0.068 & & & \\
\hline AFP & $\geq 10 \mathrm{ng} / \mathrm{ml}$ & 2.04 & $1.11-3.74$ & 0.022 & & & \\
\hline DCP & $\geq 40 \mathrm{ng} / \mathrm{ml}$ & 3.79 & $1.49-9.67$ & 0.005 & 4.99 & $1.91-13.01$ & 0.001 \\
\hline Differentiation & Poor, Moderate & 1.50 & $0.67-3.36$ & 0.330 & & & \\
\hline Growth form & Infiltrative & 1.63 & $0.82-3.24$ & 0.164 & & & \\
\hline Serosal invasion & Positive & 2.00 & $1.06-3.77$ & 0.033 & & & \\
\hline Portal vein invasion & Positive & 3.22 & $1.67-6.19$ & $<0.001$ & 5.41 & $2.69-10.87$ & $<0.001$ \\
\hline Hepatic vein invasion & Positive & 3.19 & $1.65-6.18$ & $<0.001$ & & & \\
\hline Liver cirrhosis & Present & 0.99 & $0.48-2.07$ & 0.989 & & & \\
\hline
\end{tabular}

RFS: Recurrence-free survival time ; HCC-NBNC: hepatocellular carcinoma with no virus-infected liver; AFP: $\alpha$-fetoprotein; DCP: des-gammacarboxy prothrombin; HR: hazard ratio; CI: confidence interval.

produce DCP (24). Our clinical data clearly indicate that $\mathrm{DCP}$ values increased depending on the T stage of $\mathrm{HCC}$ NBNCs. Besides HCC-BCs are derived from the damaged background liver, which is chronically exposed to longlasting hypoxia (25). Actually, DCP values of the cirrhotic liver tumors were significantly decreased.

Exome sequences of hepatocellular carcinomas have identified new mutational signatures and potential therapeutic targets (7). Depending on the risk factors of hepatocarcinogenesis, responsible gene signatures vary. For instance, CTNNB1, TERT, CDKN2A, SMRCA2 and HGF gene alterations ican be frequently found in alcohol-based hepatitis. TP53 mutation was dominant in hepatitis B cases.
In contrast, no distinct signature was identified in hepatitis C or NASH-based HCCs. Totoki et al., have revealed 30 candidate driver genes and 11 core pathway modules from 503 liver cancer genomes (8). TERT or ATRX chromation remodeler $(A T R X)$ genes are widely mutated in all virusinduced HCCs. For NBNC HCCs, AT-rich interaction domain 1A (ARIDIA) mutation is frequently found. Moore et al., have demonstrated that ARIDIA-deficient livers are more susceptible to high-fat diet-induced liver steatosis and fibrosis in mice models (26). As a detailed mechanism, Qu YL et al., have revealed that ARIDIA deficiency impairs fatty acid oxidation by epigenetically downregulating Peroxisome proliferator-activated receptor alpha (PPAR $\alpha)$ 
Table VI. Univariate and multivariable analyses of OS in HCC-BC cases.

\begin{tabular}{|c|c|c|c|c|c|c|c|}
\hline \multirow{2}{*}{\multicolumn{2}{|c|}{ Clinicopathological factors }} & \multicolumn{3}{|c|}{ Univariate analysis } & \multicolumn{3}{|c|}{ Multivariable analysis } \\
\hline & & \multirow{2}{*}{$\begin{array}{l}\mathrm{HR} \\
1.06\end{array}$} & \multirow{2}{*}{$\begin{array}{c}95 \% \mathrm{CI} \\
0.67-1.67\end{array}$} & \multirow{2}{*}{$\frac{p \text {-Value }}{0.813}$} & \multirow[t]{2}{*}{ HR } & \multirow[t]{2}{*}{$95 \% \mathrm{CI}$} & \multirow[t]{2}{*}{$p$-Value } \\
\hline Age & $\geq 65$ years & & & & & & \\
\hline Gender & Male & 1.01 & $0.59-1.71$ & 0.983 & & & \\
\hline Tumor number & Multiple & 2.23 & $1.46-3.41$ & $<0.001$ & 1.94 & $1.18-3.17$ & 0.008 \\
\hline Tumor size & $\geq 2.0 \mathrm{~cm}$ & 1.21 & $0.78-1.86$ & 0.391 & & & \\
\hline AFP & $\geq 10 \mathrm{ng} / \mathrm{ml}$ & 1.65 & $1.04-2.61$ & 0.034 & & & \\
\hline DCP & $\geq 40 \mathrm{ng} / \mathrm{ml}$ & 1.63 & $1.04-2.55$ & 0.034 & & & \\
\hline Differentiation & Poor, Moderate & 1.50 & $0.84-2.65$ & 0.169 & & & \\
\hline Growth form & Infiltrative & 2.41 & $1.48-3.91$ & $<0.001$ & & & \\
\hline Serosal invasion & Positive & 2.61 & $1.56-4.37$ & $<0.001$ & 1.82 & $1.06-3.13$ & 0.031 \\
\hline Portal vein invasion & Positive & 3.93 & $2.54-6.07$ & $<0.001$ & 2.63 & $1.58-4.38$ & $<0.001$ \\
\hline Hepatic vein invasion & Positive & 5.17 & $2.97-9.00$ & $<0.001$ & 4.73 & $2.62-8.54$ & $<0.001$ \\
\hline Liver cirrhosis & Present & 1.37 & $0.90-2.09$ & 0.138 & & & \\
\hline
\end{tabular}

OS: Overall survival time; HCC-BC: hepatocellular carcinoma with virus-infected liver; AFP: $\alpha$-fetoprotein; DCP: des-gamma-carboxy prothrombin; HR: hazard ratio; CI: confidence interval.

Table VII. Univariate and multivariable analyses of OS in HCC-NBNC cases.

\begin{tabular}{|c|c|c|c|c|c|c|c|}
\hline \multirow{2}{*}{\multicolumn{2}{|c|}{ Clinicopathological factors }} & \multicolumn{3}{|c|}{ Univariate analysis } & \multicolumn{3}{|c|}{ Multivariable analysis } \\
\hline & & \multirow{2}{*}{$\frac{\mathrm{HR}}{2.14}$} & \multirow{2}{*}{$\begin{array}{c}95 \% \mathrm{CI} \\
0.48-9.60\end{array}$} & \multirow{2}{*}{$\frac{p \text {-Value }}{0.320}$} & \multirow[t]{2}{*}{ HR } & \multirow[t]{2}{*}{$95 \% \mathrm{CI}$} & \multirow[t]{2}{*}{$p$-Value } \\
\hline Age & $\geq 65$ years & & & & & & \\
\hline Gender & Male & 1.16 & $0.26-5.22$ & 0.845 & & & \\
\hline Tumor number & Multiple & 1.91 & $0.53-6.89$ & 0.321 & & & \\
\hline Tumor size & $\geq 2.0 \mathrm{~cm}$ & 4.46 & $0.58-34.22$ & 0.150 & & & \\
\hline AFP & $\geq 10 \mathrm{ng} / \mathrm{ml}$ & 2.91 & $0.91-9.27$ & 0.071 & & & \\
\hline DCP & $\geq 40 \mathrm{ng} / \mathrm{ml}$ & N/A & N/A & N/A & $\mathrm{N} / \mathrm{A}$ & N/A & $\mathrm{N} / \mathrm{A}$ \\
\hline Differentiation & Poor, Moderate & 1.64 & $0.36-7.38$ & 0.522 & & & \\
\hline Growth form & Infiltrative & 2.53 & $0.83-7.75$ & 0.104 & & & \\
\hline Serosal invasion & Positive & 7.42 & $1.96-28.05$ & 0.003 & 4.74 & $1.13-19.87$ & 0.033 \\
\hline Portal vein invasion & Positive & 5.07 & $1.70-15.17$ & 0.004 & 8.26 & $1.88-36.22$ & 0.005 \\
\hline Hepatic vein invasion & Positive & 5.89 & $1.87-18.52$ & 0.002 & & & \\
\hline Liver cirrhosis & Present & 1.60 & $0.50-5.12$ & 0.424 & & & \\
\hline
\end{tabular}

OS: Overall survival time; HCC-NBNC: Hepatocellular carcinoma with no virus-infected liver; AFP: $\alpha$-fetoprotein; DCP: des-gamma-carboxy prothrombin; HR: hazard ratio; CI: confidence interval; N/A: not adequate.

and other metabolism-related genes, such as carnitine palmitoyltransferase $1 \mathrm{~A}(C P T 1 A)$ and acyl-CoA oxidase 1 (ACOX1) (27).

This study has some limitations. First, this is a retrospective study from a single-institution with a modest sample size. Further confirmation with large multicenter data is required. Second, the mechanism of DCP elevation in HCC-NBNC should be explained by specific molecular characteristics, including PNPLA3 mutation, ARIDIA deficiency or lipid metabolism-related genes in non-hepatitis livers in future studies.

In conclusion, AFP elevation and DCP elevation were differentially observed depending on the background liver status. Hepatocarcinogenesis in NASH liver was specific to DCP elevation, rather than AFP. DCP seems to be a significant predictive serum marker of survival outcomes, especially for HCC-NBNC cases.

\section{Conflicts of Interest}

The Authors declare no conflicts of interest.

\section{Authors' Contributions}

MH, SY and YO designed the project. MH, NT,YO, HT, YI, FS, NT and MK collected the clinical data. MH, NT and YO analyzed the data. 


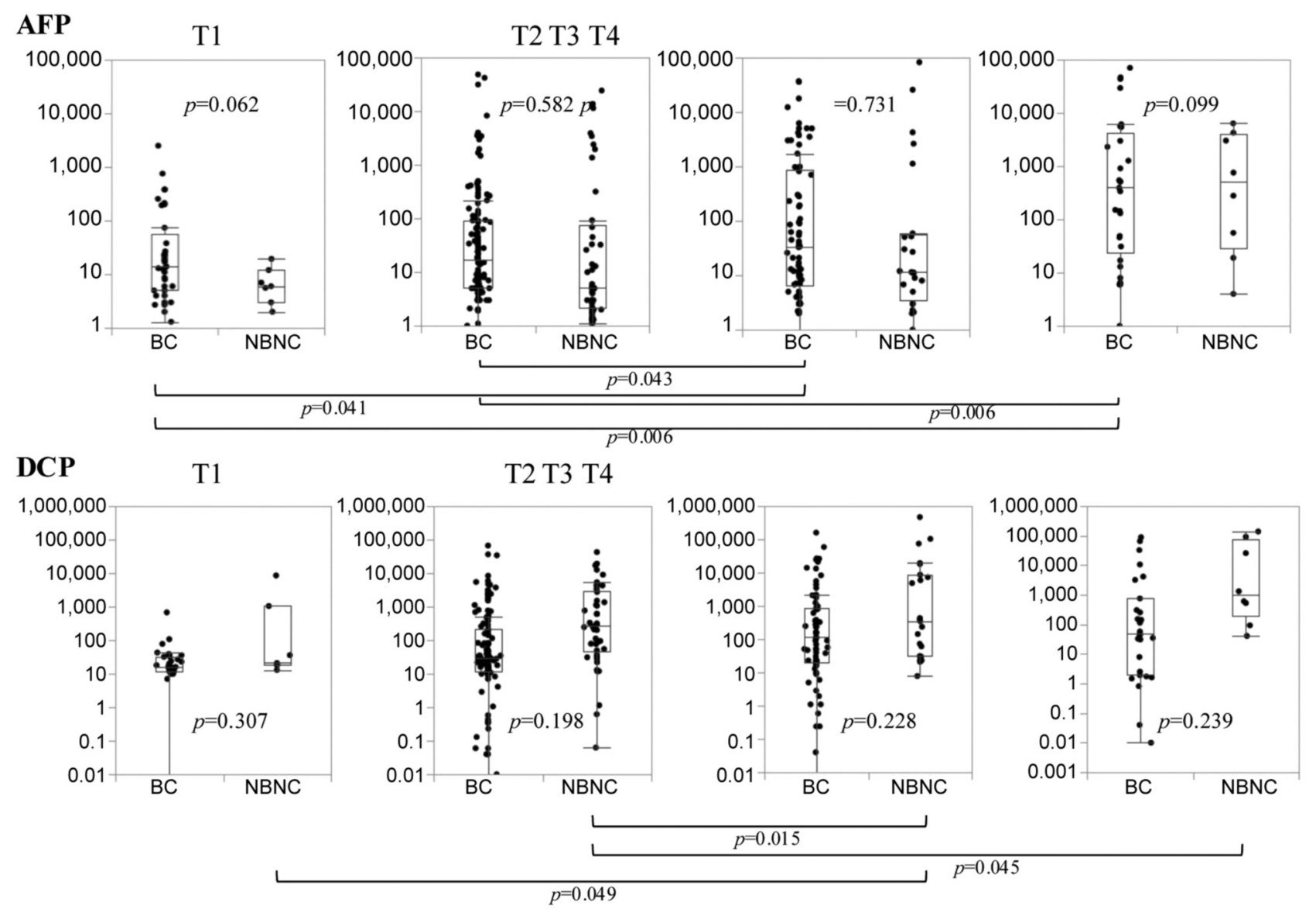

Figure 4. Distribution of preoperative AFP and DCP values according to histological $T$ grades. AFP values of HCC-BC cases are gradually increased in parallel with T grades, whereas of HCC-NBNC cases did not. On the contrary, HCC-NBNC cases showed a steady increase in DCP values with T stage, while HCC-BC cases showed no increase. AFP: Alpha-fetoprotein; DCP: des-gamma-carboxy prothrombin; HCC-BC: hepatocellular carcinoma with virus-infected liver; HCC-NBNC: hepatocellular carcinoma with no virus-infected liver.

AFP

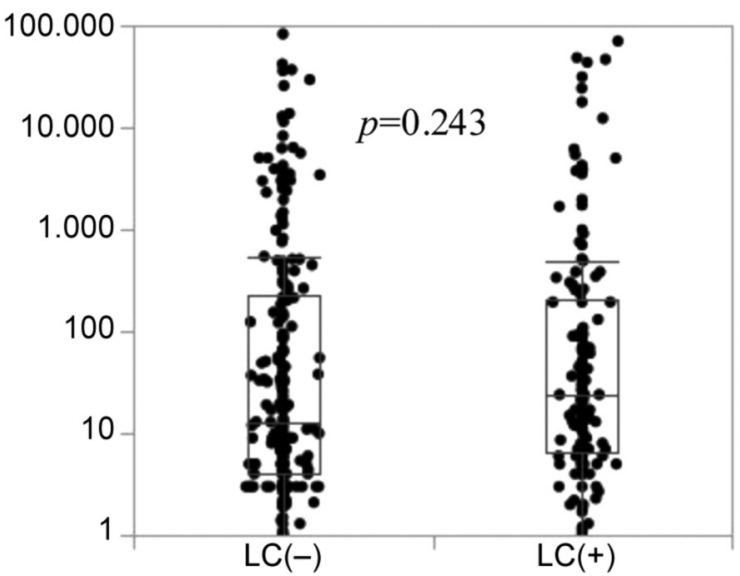

DCP

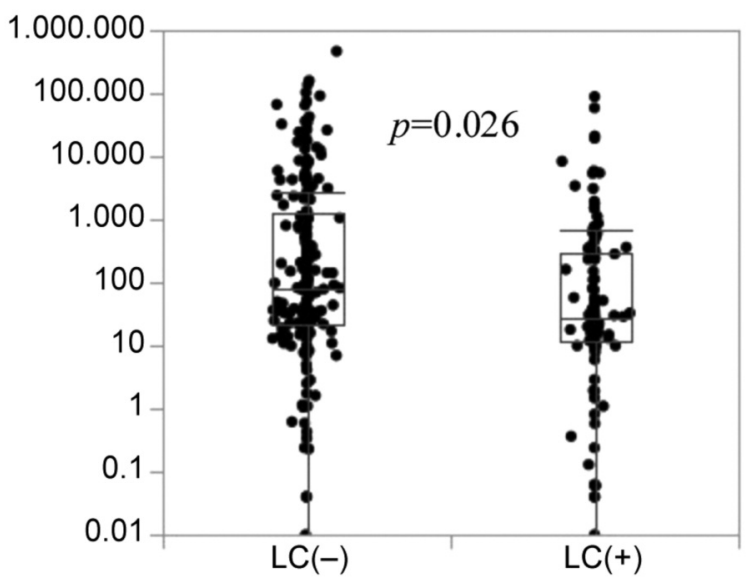

Figure 5. Association between each tumor marker and liver cirrhosis (LC). AFP values showed no decrease in LC cases, whereas DCP values decreased in LC cases. AFP: Alpha-fetoprotein, DCP: des-gamma-carboxy prothrombin. 
MH and SY checked and approved all the statistical analyses. MH prepared the manuscript and DS, NH, CT, GN, MK and YK revised it.

\section{References}

1 Bray F, Ferlay J, Soerjomataram I, Siegel RL, Torre LA and Jemal A: Global cancer statistics 2018: GLOBOCAN estimates of incidence and mortality worldwide for 36 cancers in 185 countries. CA Cancer J Clin 68(6): 394-424, 2018. PMID: 30207593. DOI: $10.3322 /$ caac. 21492

2 Forner A, Llovet JM and Bruix J: Hepatocellular carcinoma. Lancet 379(9822): 1245-1255, 2012. PMID: 22353262. DOI: 10.1016/S0140-6736(11)61347-0

3 El-Serag HB: Hepatocellular carcinoma. N Engl J Med 365(12): 1118-1127, 2011. PMID: 21992124. DOI: 10.1056/NEJMra 1001683

4 Utsunomiya T, Shimada M, Kudo M, Ichida T, Matsui O, Izumi N, Matsuyama Y, Sakamoto M, Nakashima O, Ku Y, Takayama $\mathrm{T}$, Kokudo $\mathrm{N}$ and Liver Cancer Study Group of Japan.: A comparison of the surgical outcomes among patients with HBVpositive, HCV-positive, and non-B non-C hepatocellular carcinoma: a nationwide study of 11,950 patients. Ann Surg 261(3): 513-520, 2015. PMID: 25072437. DOI: 10.1097/ SLA.0000000000000821

5 Brunner SF, Roberts ND, Wylie LA, Moore L, Aitken SJ, Davies SE, Sanders MA, Ellis P, Alder C, Hooks Y, Abascal F, Stratton MR, Martincorena I, Hoare M and Campbell PJ: Somatic mutations and clonal dynamics in healthy and cirrhotic human liver. Nature 574(7779): 538-542, 2019. PMID: 31645727. DOI: 10.1038/s41586-019-1670-9

6 Letouzé E, Shinde J, Renault V, Couchy G, Blanc JF, Tubacher E, Bayard Q, Bacq D, Meyer V, Semhoun J, Bioulac-Sage P, Prévôt S, Azoulay D, Paradis V, Imbeaud S, Deleuze JF and Zucman-Rossi J: Mutational signatures reveal the dynamic interplay of risk factors and cellular processes during liver tumorigenesis. Nat Commun 8(1): 1315, 2017. PMID: 29101368. DOI: 10.1038/s41467-017-01358-x

7 Schulze K, Imbeaud S, Letouzé E, Alexandrov LB, Calderaro J, Rebouissou S, Couchy G, Meiller C, Shinde J, Soysouvanh F, Calatayud AL, Pinyol R, Pelletier L, Balabaud C, Laurent A, Blanc JF, Mazzaferro V, Calvo F, Villanueva A, Nault JC, Bioulac-Sage P, Stratton MR, Llovet JM and Zucman-Rossi J: Exome sequencing of hepatocellular carcinomas identifies new mutational signatures and potential therapeutic targets. Nat Genet 47(5): 505-511, 2015. PMID: 25822088. DOI: 10.1038/ ng. 3252

8 Totoki Y, Tatsuno K, Covington KR, Ueda H, Creighton CJ, Kato M, Tsuji S, Donehower LA, Slagle BL, Nakamura H, Yamamoto S, Shinbrot E, Hama N, Lehmkuhl M, Hosoda F, Arai Y, Walker K, Dahdouli M, Gotoh K, Nagae G, Gingras MC, Muzny DM, Ojima H, Shimada K, Midorikawa Y, Goss JA, Cotton R, Hayashi A, Shibahara J, Ishikawa S, Guiteau J, Tanaka M, Urushidate T, Ohashi S, Okada N, Doddapaneni H, Wang M, Zhu Y, Dinh H, Okusaka T, Kokudo N, Kosuge T, Takayama T, Fukayama M, Gibbs RA, Wheeler DA, Aburatani H and Shibata T: Trans-ancestry mutational landscape of hepatocellular carcinoma genomes. Nat Genet 46(12): 1267-1273, 2014. PMID: 25362482. DOI: $10.1038 / n g .3126$

9 Edman JC, Gray P, Valenzuela P, Rall LB and Rutter WJ: Integration of hepatitis $\mathrm{B}$ virus sequences and their expression in a human hepatoma cell. Nature 286(5772): 535-538, 1980. PMID: 6250075. DOI: 10.1038/286535a0

10 Jhunjhunwala S, Jiang Z, Stawiski EW, Gnad F, Liu J, Mayba O, Du P, Diao J, Johnson S, Wong KF, Gao Z, Li Y, Wu TD, Kapadia SB, Modrusan Z, French DM, Luk JM, Seshagiri S and Zhang Z: Diverse modes of genomic alteration in hepatocellular carcinoma. Genome Biol 15(8): 436, 2014. PMID: 25159915. DOI: $10.1186 / \mathrm{s} 13059-014-0436-9$

11 Sung WK, Zheng H, Li S, Chen R, Liu X, Li Y, Lee NP, Lee WH, Ariyaratne PN, Tennakoon C, Mulawadi FH, Wong KF, Liu AM, Poon RT, Fan ST, Chan KL, Gong Z, Hu Y, Lin Z, Wang G, Zhang Q, Barber TD, Chou WC, Aggarwal A, Hao K, Zhou W, Zhang C, Hardwick J, Buser C, Xu J, Kan Z, Dai H, Mao M, Reinhard C, Wang J and Luk JM: Genome-wide survey of recurrent $\mathrm{HBV}$ integration in hepatocellular carcinoma. Nat Genet 44(7): 765-769, 2012. PMID: 22634754. DOI: 10.1038/ ng.2295

12 Kutlu O, Kaleli HN and Ozer E: Molecular Pathogenesis of Nonalcoholic Steatohepatitis- (NASH-) Related Hepatocellular Carcinoma. Can J Gastroenterol Hepatol 2018: 8543763, 2018. PMID: 30228976. DOI: 10.1155/2018/8543763

13 Song T, Wang L, Xin R, Zhang L and Tian Y: Evaluation of serum AFP and DCP levels in the diagnosis of early-stage HBVrelated HCC under different backgrounds. J Int Med Res 48(10): 300060520969087, 2020. PMID: 33135527. DOI: 10.1177/ 0300060520969087

14 Makuuchi M and Kokudo N: Clinical practice guidelines for hepatocellular carcinoma: the first evidence based guidelines from Japan. World J Gastroenterol 12(5): 828-829, 2006. PMID: 16521207. DOI: 10.3748/wjg.v12.i5.828

15 Wakiyama S, Matsumoto M, Haruki K, Gocho T, Sakamoto T, Shiba H, Futagawa Y, Ishida Y and Yanaga K: Clinical features and outcome of surgical patients with non-b non-c hepatocellular carcinoma. Anticancer Res 37(6): 3207-3213, 2017. PMID: 28551666. DOI: 10.21873/anticanres.11682

16 El Raziky M, Attia D, El Akel W, Shaker O, Khatab H, Abdo S, Elsharkawy A and Esmat G: Hepatic fibrosis and serum alphafetoprotein (AFP) as predictors of response to HCV treatment and factors associated with serum AFP normalisation after treatment. Arab J Gastroenterol 14(3): 94-98, 2013. PMID: 24206736. DOI: 10.1016/j.ajg.2013.08.005

17 Zheng Y, Zhu M and Li M: Effects of alpha-fetoprotein on the occurrence and progression of hepatocellular carcinoma. J Cancer Res Clin Oncol 146(10): 2439-2446, 2020. PMID: 32725355. DOI: $10.1007 / \mathrm{s} 00432-020-03331-6$

18 Zhang H, Cao D, Zhou L, Zhang Y, Guo X, Li H, Chen Y, Spear BT, Wu JW, Xie Z and Zhang WJ: ZBTB20 is a sequencespecific transcriptional repressor of alpha-fetoprotein gene. Sci Rep 5: 11979, 2015. PMID: 26173901. DOI: 10.1038/srep11979

19 Yue P, Gao ZH, Xue X, Cui SX, Zhao CR, Yuan Y, Yin Z, Inagaki Y, Kokudo N, Tang W and Qu XJ: Des- $\gamma$-carboxyl prothrombin induces matrix metalloproteinase activity in hepatocellular carcinoma cells by involving the ERK1/2 MAPK signalling pathway. Eur J Cancer 47(7): 1115-1124, 2011. PMID: 21349701. DOI: 10.1016/j.ejca.2011.01.017

20 Taniguchi T, Kishi K, Nakagawa T, Tanaka H, Tanaka T, Tomonari T, Okamoto K, Sogabe M, Miyamoto H, Okahisa T, Muguruma N, Kajimoto M, Sagawa I and Takayama T: Poly(ADP-Ribose) Polymerase-1 promotes prothrombin gene transcription and produces des-gamma-carboxy prothrombin in 
hepatocellular carcinoma. Digestion 95(3): 242-251, 2017. PMID: 28384634. DOI: 10.1159/000470837

21 Mukhopadhyay P, Horváth B, Rajesh M, Varga ZV, Gariani K, Ryu D, Cao Z, Holovac E, Park O, Zhou Z, Xu MJ, Wang W, Godlewski G, Paloczi J, Nemeth BT, Persidsky Y, Liaudet L, Haskó G, Bai P, Boulares AH, Auwerx J, Gao B and Pacher P: PARP inhibition protects against alcoholic and non-alcoholic steatohepatitis. J Hepatol 66(3): 589-600, 2017. PMID: 27984176. DOI: 10.1016/j.jhep.2016.10.023

22 Yamazaki S, Takayama T, Kurokawa T, Shimamoto N, Mitsuka Y, Yoshida N, Higaki T and Sugitani M: Next-generation desr-carboxy prothrombin for immunohistochemical assessment of vascular invasion by hepatocellular carcinoma. BMC Surg 20(1): 201, 2020. PMID: 32928172. DOI: 10.1186/s12893-02000862-0

23 Suzuki H, Murata K, Gotoh T, Kusano M, Okano H, Oyamada T, Yasuda Y, Imamura M, Kudo M, Mizokami M and Sakamoto A: Phenotype-dependent production of des- $\gamma$-carboxy prothrombin in hepatocellular carcinoma. J Gastroenterol 46(10): 1219-1229, 2011. PMID: 21744129. DOI: 10.1007/s00535-011-0432-8

24 Höckel M and Vaupel P: Biological consequences of tumor hypoxia. Semin Oncol 28(2 Suppl 8): 36-41, 2001. PMID: 11395851.
25 Zhu C, Liu X, Wang S, Yan X, Tang Z, Wu K, Li Y and Liu F: Hepatitis $\mathrm{C}$ virus core protein induces hypoxia-inducible factor $1 \alpha$-mediated vascular endothelial growth factor expression in Huh7.5.1 cells. Mol Med Rep 9(5): 2010-2014, 2014. PMID: 24626461. DOI: $10.3892 / \mathrm{mmr} .2014 .2039$

26 Moore A, Wu L, Chuang JC, Sun X, Luo X, Gopal P, Li L, Celen C, Zimmer M and Zhu H: Arid1a loss drives nonalcoholic steatohepatitis in mice through epigenetic dysregulation of hepatic lipogenesis and fatty acid oxidation. Hepatology 69(5): 1931-1945, 2019. PMID: 30584660. DOI: 10.1002/hep.30487

27 Qu YL, Deng CH, Luo Q, Shang XY, Wu JX, Shi Y, Wang L and Han ZG: Arid1a regulates insulin sensitivity and lipid metabolism. EBioMedicine 42: 481-493, 2019. PMID: 30879 920. DOI: 10.1016/j.ebiom.2019.03.021

Received January 16, 2021

Revised February 6, 2021

Accepted February 10, 2021 